\title{
Review: Natural tracers in fractured hard-rock aquifers in the Austrian part of the Eastern Alps-previous approaches and future perspectives for hydrogeology in mountain regions
}

\author{
Sylke Hilberg ${ }^{1}$
}

Received: 31 August 2015 / Accepted: 7 March 2016/Published online: 28 March 2016

(C) The Author(s) 2016. This article is published with open access at Springerlink.com

\begin{abstract}
Extensive in-depth research is required for the implementation of natural tracer approaches to hydrogeological investigation to be feasible in mountainous regions. This review considers the application of hydrochemical and biotic parameters in mountain regions over the past few decades with particular reference to the Austrian Alps, as an example for alpine-type mountain belts. A brief introduction to Austria's hydrogeological arrangement is given to show the significance of fractured hard-rock aquifers for hydrogeological science as well as for water supply purposes. A literature search showed that research concerning fractured hard-rock aquifers in Austria is clearly underrepresented to date, especially when taking the abundance of this aquifer type and the significance of this topic into consideration. The application of abiotic natural tracers (hydrochemical and isotope parameters) is discussed generally and by means of examples from the Austrian Alps. The potential of biotic tracers (microbiota and meiofauna) is elucidated. It is shown that the meiofauna approach to investigating fractured aquifers has not yet been applied in the reviewed region, nor worldwide. Two examples of new approaches in mountainous fractured aquifers are introduced: (1) use of $\mathrm{CO}_{2}$ partial pressure and calcite saturation of spring water to reconstruct catchments and flow dynamics (abiotic approach), and, (2) consideration of hard-rock aquifers as habitats to reconstruct aquifer conditions (biotic approach).
\end{abstract}

Keywords Fracture rocks $\cdot$ Hydrochemistry $\cdot$ Ecology Natural tracers $\cdot$ Austria

Sylke Hilberg

sylke.hilberg@sbg.ac.at

1 Department of Geography and Geology, University of Salzburg, Hellbrunner Str. 34, 5020 Salzburg, Austria

\section{Introduction}

Approximately $25 \%$ of the Earth's total land area is mountainous (Meybeck et al. 2001). This mountainous part of the Earth's land area plays a major role in water supply for the remaining nearly three-quarters, which is characterised as subhorizontal or flat landscape below an elevation of 1,000 $\mathrm{m}$ above sea level (asl); thus, mountainous areas are sometimes called "water towers", which, from the hydrological perspective, indicates their importance for the global water supply (Liniger et al. 1998; Viviroli et al. 2007).

Large mountain belts abound in North and South America (e.g. Andes, Rocky Mountains), in Africa (e.g. Grand Atlas Mountains), Asia (e.g. Himalayas, Altai Mountains), Australia and New Zealand (Australian Alps, Southern Alps), and in Europe (Alps, Apennines, Carpathians, Caucasus, Scandinavian orogenic belt). In terms of many hydrogeological aspects, these alpine type orogenic belts can be regarded as similar. The predominance of fractured (or karstic) hard rock aquifers, a pronounced relief with elevation variations of several thousands of meters, function as a continental divide and the complex internal structure of folded, fractured and thrusted nappes of various lithology, are typical characteristics of alpine type mountain regions, and they affect hydrogeological properties and processes. Thus, many of the findings and methods developed for one of these mountain belts are transferable to other regions. Additionally existing methodological shortcomings and knowledge gaps in alpine hydrogeology are more or less comparable for all alpine type mountain ranges.

This paper focuses on the Eastern Alps (a Central European mountain range) and particularly on the Austrian part. Aside from the aforementioned similarities with other alpine mountain belts, the Alps are characterised by some special features such as range 
of elevation (500 up to nearly 4,000 m asl), climate and high population density, and by its lithological distribution. For instance, the up to 2,000-m thick and widespread karst aquifer of the Northern Calcareous Alps is a special feature of the European Eastern Alps that does not exist with comparable prevalence in other alpine type mountains; thus, many but presumably not all the topics discussed here may be transferred to other mountain ranges in the world.

Hydrogeology in mountain areas is mainly concerned with hard rock aquifers with conduit or diffuse flow conditions. Fractured rock environments are important as a field of study because of their abundance, the difficulties in predicting their behaviour, and their increasing importance for water supply (Glynn and Plummer 2005). For a comprehensive hydrogeological model of a fractured hard-rock aquifer, aside from geology (e.g. Neumann 2005), abiotic and biotic processes must be considered.

Some important information about the aquifer characteristics is reflected in the groundwater components such as dissolved main ions and trace elements, mineral particles, stable or radioactive isotope composition, organic material, and organisms. Understanding the processes leading to the groundwater composition is an important premise to understanding flow systems (as introduced by Toth 1999) in hard rock aquifers. Thus, physiochemical and biological natural tracers have a high potential to determine catchments and infiltration areas, aquifer lithology, flow dynamics, and mean residence times in all kinds of aquifers.

This paper gives an overview of different types of fractured hard rock aquifers and their characteristics with the example of the Austrian Eastern Alps and some brief glances at studies in other mountain regions, and shows how hydrochemical and isotope data as well as biological data are currently used as hydrogeological indicators. In addition, two approaches to improve qualitative methods in hard rock hydrogeology are discussed: (1) the assessment of hydrochemical data, particularly considering the carbon acid system and processes in the unsaturated zone (Hilberg 2011; Hilberg et al. 2013), and (2) using groundwater inhabitants as hydrogeological agents (Eisendle-Flöckner and Hilberg 2015).

The article is organised into chapters dealing with the following topics:

- Hydrogeological overview of the Austrian Alps

- The use of abiotic natural tracers in hard rock aquifers

- Biotic natural tracer use in hydrogeology

- Some thoughts about future perspectives for hard rock hydrogeology in alpine environments

\section{Hydrogeological overview of the Austrian Alps}

With regard to the hydrogeological characterisation of the alpine range, the Austrian part can be divided into greater geological areas that are more or less arranged from north to south (Fig. 1; Table 1). Whilst porous aquifers are dominant in the alpine forelands and in intra-alpine valleys, karstic and fractured aquifers and hard rock aquitards are characteristic for mountain hydrogeology.

\section{Molasse zone}

The northern foreland of the Alps reaches a maximum height of $400 \mathrm{~m}$ asl in a smooth hilly topography and is characterised by mean precipitation amounts of $800-1,000 \mathrm{~mm} / \mathrm{year}$ (Austrian Ministry of Life 2012). The surface area is covered by deep soils and rich vegetation, and is characterised by regionally intensive agricultural use.

Facies and structural history of the Molasse zone are described by Berge and Veal (2005). The aquifer consists of sands and conglomerates in alternation with marl or clay; in deeper sections the alternation is in the form of consolidated marl- or claystone. As well as crystalline components, carbonatic conglomerates dominate in large areas of the Molasse zone (Goeppert et al. 2011). Aside from porous aquifers in unconsolidated upper layers with hydraulic conductivities in the range of $10^{-3}$ to $10^{-5} \mathrm{~m} / \mathrm{s}$ (Gattinger 1980), fractured as well as karst aquifers are present within this northernmost part of the Eastern Alps.

The most important process of groundwater recharge is laminar infiltration of rain water from the ground surface. Alternating sequences of medium-grained sand (aquifer) and fine-grained clay or marl (aquitard) create a multi-aquifer formation and local artesian basins (Andrews et al. 1985; Schubert 2003).

Due to the share of carbonates in the sedimentary fill, the groundwater quality in the Molasse zone is characterised by the $\mathrm{Ca}-\mathrm{Mg}-\mathrm{HCO}_{3}$ water type (Kilchmann et al. 2004), alkaline $\mathrm{pH}$-values and, compared to other alpine hard rock environments, high electrical conductivity values (around $600 \mu \mathrm{S} /$ cm, Austrian Geological Survey 2004; Kralik et al. 2005). Three groups of groundwater were defined within the Molasse basin of Upper Austria (Andrews et al. 1985): (1) shallow local groundwater systems with oxygen-rich water, calcite saturation and recent tritium values, (2) and (3) both deep and regional circulating groundwater with residence times of several hundreds and thousands of years, respectively under conditions of oxygen scarcity.

\section{Rhenodanubian Flysch zone (RFZ)}

The RFZ north of the Northern Calcareous Alps (NCA) is characterised by a hilly landscape with the highest elevations 


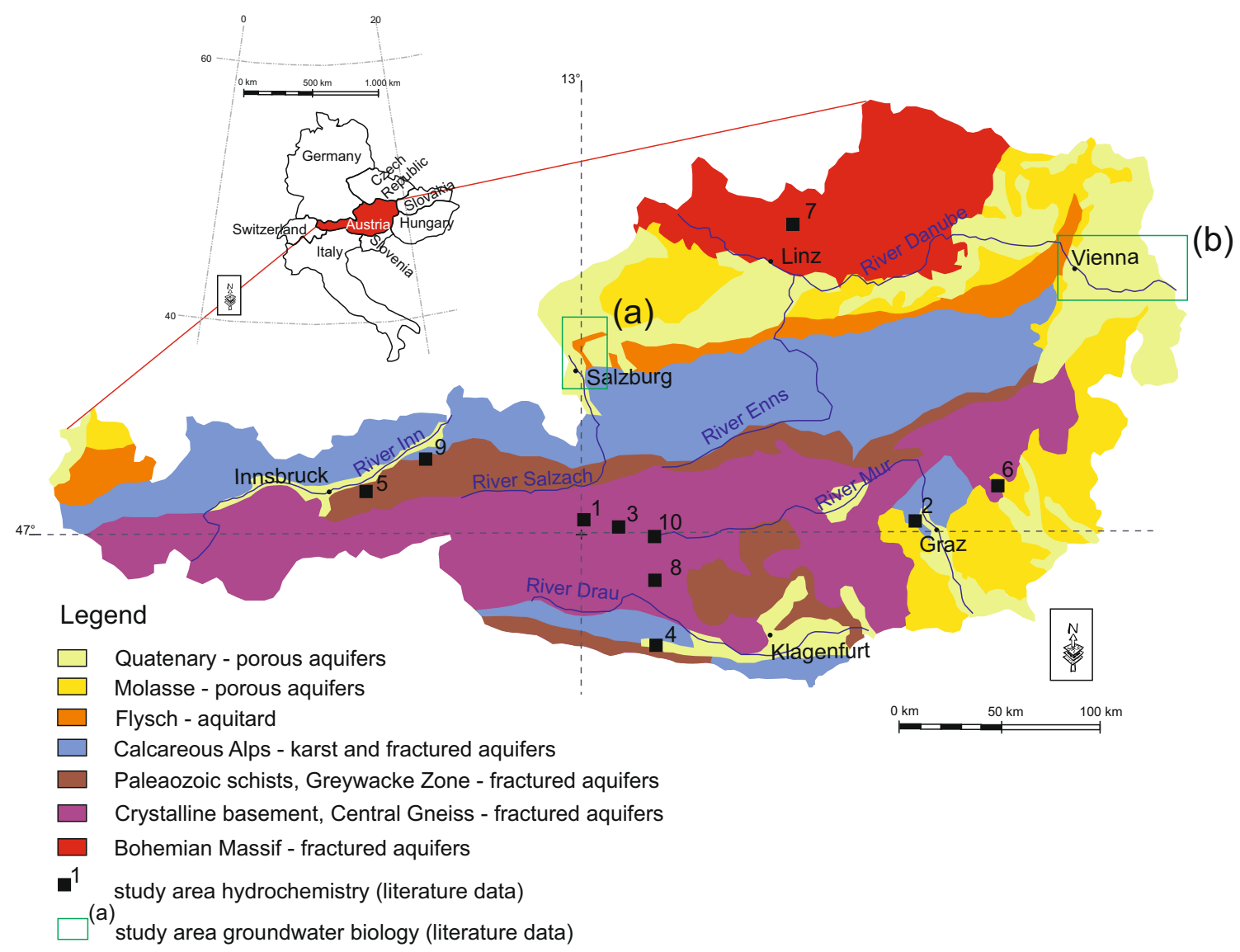

Fig. 1 Overview of Austrian aquifers (map simplified after Gattinger 1980). 1 Gastein thermal springs, 2 Plabutsch Tunnel, 3 Tauern Tunnel, 4 Förolach Tunnel, 5 Eiblschrofen, 6 Ringkogel, 7 Mühlviertel, 8 Reißeck, 9 Auffach, 10 Hintermuhr. (a) Study area Salzburg Basin, (b) Study area Danube Aquifer

in the range of $1,000 \mathrm{~m}$ asl; details about tectonics and facies are described by Berge and Veal (2005) and Wagreich et al. (2006), respectively.

Despite precipitation amounts of $1,300 \mathrm{~mm} /$ year (Austrian Ministry of Life 2012), there is a lack of groundwater in this geological unit. The dominant clay- and marlstones in this region are of very low permeability. Groundwater recharge is low and springs are rare. The mostly fine-grained consolidated sediments show a low effective primary matrix porosity. Fractures resulting from tectonic stress are tight and usually re-filled with fine-grained material; thus, there is a lack of interconnected open voids and groundwater flow is generally only possible in the uppermost zone within very local flow systems as the result of weathering structures (Schubert 2003).
Notwithstanding this, findings from the northern Apennines region (Gargini et al. 2008) contradict the general hydrogeological assessment of Flysch sediments. Similar to the facies of the RFZ, the northern Apennines Flysch sediments consist of silicoclastic and marlstone turbidites within an orogenic thrust-folds belt and were previously considered as aquitards. New insights from the tunnel boring for the high speed railway connection Bologna-Florence lead to a new hydrogeological assessment of this nappe complex. Here, locally huge amounts of tunnel inflow and seasonal effects on the hydrogeological system within the turbidites were observed. Based on a large dataset from the railway project, Gargini et al. (2008) identified different kinds of flow systems. Shallow-slope-controlled flow systems are basically within
Table 1 Overview of Austria's greater geological units and their major and subordinate aquifer types

\begin{tabular}{lll}
\hline (Hydro)geological area & Major aquifer type & Subordinate aquifer type \\
\hline Molasse zone & Porous aquifer & Fractured aquifer, karst aquifer \\
Flysch zone & Aquitard & Fractured aquifer \\
Calcareous Alps & Karst aquifer & Fractured aquifer \\
Greywacke zone & Fractured aquifer & Karst aquifer, aquitard \\
Central Gneiss zone & Fractured aquifer & - \\
\hline
\end{tabular}


the weathered uppermost zones, are gravity driven and of local scale. Tectonically controlled flow systems are controlled by extensional processes and are characterised as deep flow systems of regional scale and trans-watershed in nature. Although no comparable findings were observed in the RFZ to date, the general assessment of the alpine RFZ as an aquitard should be reconsidered due to the observations in the Apennines Flysch sediments.

\section{Northern and Southern Calcareous Alps}

The large Late Permian to Cretaceous carbonate belts along the northern and southern margin of the Alps provide the main carbonate aquifers in Austria and represent the most important drinking-water reservoirs for some of the bigger Austrian cities (Vienna, Salzburg, Innsbruck; Schubert 2000; Plan et al. 2008). Mean precipitation amounts are very variable with peak values around 2,000 mm/year (Austrian Ministry of Life 2012).

The complex stratigraphy of the Northern Calcareous Alps (NCA) has significant influence on its hydrogeological characteristics. Late Permian evaporitic sediments (gypsum, anhydrite, halite), the so-called "Haselgebirge", form the basis of the NCA nappe complex and are the source of the majority of highly mineralised springs along the northern range of the NCA. The overlying Lower to Middle Triassic units are dominated by dolomitic lithology, the so-called "Hauptdolomit" facies, which is predominant along the northernmost part of the NCA and can be characterised as fractured-karstic-porous aquifers (Maloszewski et al. 2002; Hilberg and Schneider 2011). Upper Triassic, Jurassic, and Cretaceous sediments are carbonate dominated and provide extensive karst aquifers.

Compared to highly permeable conduits, the matrix permeability of carbonate rocks is very low and its influence on the hydrogeological processes in karst aquifers is negligible (Bakalowicz 2005). Basically, carbonate regions are supposed to provide karst aquifers with highly permeable solution conduits and sinkholes. Within the Calcareous Alps (Northern and Southern) more than $75 \%$ of the precipitation infiltrates quickly through sinkholes into the karst system (Gattinger 1980) and the soil cover (Rendzina soil) is thin or non-existent. A major characteristic of karst aquifers is the very short mean residence time of the fast flow component in the range of only a few hours or days (Lauber and Goldscheider 2014) associated with fast flow velocities of up to several hundreds of meters per hour (Bakalowicz 2005; Vigna and Banzato 2015) and high variations in spring discharge. Single karst springs with a high discharge may drain large catchments (Rehrl and Birk 2010).

Some examples of very different kinds of carbonatic aquifers - karstic and non-karstic one - are described from the southern Piedmont region in Italy (Vigna and Banzato 2015). Three basic conceptual models are postulated here:
(1) a system with dominant drainage having a high degree of karstification, a high flow velocity, and a lack of a saturated zone, (2) a system with interconnected drainage, and (3) a system with dispersive drainage - with a low degree of karstification, interconnected network of fractures, low flow velocities, high water level, and a thick saturated zone. It can be assumed that this classification of carbonate aquifers is also valid for the Northern and Southern Calcareous Alps in Austria, particularly with regard to less karstifiable dolomitic units.

The higher the degree of karstification, the higher the variability of spring discharge and, due to thinning effects, the water composition. The base flow in carbonate aquifers is characterised by calcite saturation (Kilchmann et al. 2004), slightly alkaline $\mathrm{pH}$-values, electrical conductivity values in the range of $200-400 \mu \mathrm{S} / \mathrm{cm}$, and a $\mathrm{Ca}-\mathrm{Mg}-\mathrm{HCO}_{3}$-water type (Austrian Geological Survey 2004; Kralik et al. 2005).

\section{Greywacke zone}

The Greywacke zone is a $450-\mathrm{km}$ long and at most $23-\mathrm{km}$ wide east-west-trending strip (Schönlaub 1980) that divides the NCA from the Penninic Tauern Window (Rantitsch and Judik 2009). This belt consists of a lithological mixture of metamorphic silicate and carbonate ranges (Schönlaub 1980). The annual precipitation amount is in the range of 1 , $500 \mathrm{~mm} /$ year (Austrian Ministry of Life 2012). Due to the wide lithological variations, the Greywacke zone has various kinds of aquifers (Gattinger 1980).

While the carbonate-dominated regions provide local karst aquifers (Schubert 2003), phyllites or schists can be characterised as aquitards, or locally as fractured aquifers with low permeability. Here groundwater flow is restricted to open intra-connected fractures that are comparably sparse. Phyllites and schists tend to react to tectonic stress in a ductile manner and preferably form folds rather than fractures. In addition, fine-grained weathering material tends to fill open fractures. Long mean residence times are the consequence of the low flow conditions. Springs are frequent but usually rather small (Gattinger 1980).

The groundwater quality depends on the aquifer lithology, and is therefore very variable with mostly alkaline $\mathrm{pH}$-values and higher mineralisation in carbonate units, while slightly acidic groundwater and low mineralisation are typical in the fractured parts of the mountain range (Austrian Geological Survey 2004).

\section{Central Gneiss zone}

The Central Gneiss zone and its schistose frame (so-called "Schieferhülle") reach the highest elevations within the Austrian Alps with a maximum of 3,798 m asl (summit of Großglockner). Precipitation amounts can reach 2,500 mm/ 
year in the highest regions (Austrian Ministry of Life 2012). The central crystalline zone in Austria is represented by, e.g. the Tauern Window which consists of mica schists and phyllites in the northern and southern peripheral zone, and gneisses in its central part (Thiele 1980). The hydrogeological characterisation of schists and phyllites in the "Schieferhülle" are comparable to those of the non-karstifiable parts of the Greywacke zone.

In magmatic or metamorphic crystalline rocks, the matrix porosity can basically be considered to be negligible (Lachassagne et al. 2001, Neumann 2005; Pochon et al. 2008). Hydraulically relevant objects are (1) open fractures with a width of up to several decimetres as a result of tectonic stress (Caine et al. 1996), and (2) weathered layers (Welch and Allen 2014). Hydraulic conductivities in the range of $10^{-11}-10^{-7} \mathrm{~m} / \mathrm{s}$ were observed in the core zone of a major crystalline fault in a local study area in Eastern Austria (Winkler et al. 2010).

The conceptual model by Welch and Allen (2014) describes the layered structure of a granitic hard rock aquifer consisting of a soil layer with high hydraulic conductivity $\left(10^{-4}-10^{-2} \mathrm{~m} / \mathrm{s}\right)$, saprolite (in the uppermost part) and weathered fractured hard rocks (conductivity $10^{-8}-10^{-5}$ $\mathrm{m} / \mathrm{s}$ ). Due to compaction and the absence of weathering influences, the conductivity decreases with depth (Welch and Allen 2014). At greater depths (below $200 \mathrm{~m}$ ) the regional estimates for crystalline mountain settings are in the range of $10^{-8}-10^{-7} \mathrm{~m} / \mathrm{s}$. Investigations in the Central Alps zone in Switzerland (Masset and Loew 2010, Beatrizotti 1996, Pochon et al. 2008) and deeply weathered crystalline aquifers in India (Dewandel et al. 2011) have shown that the hydraulic conductivity of crystalline units can vary between $10^{-10}$ and $10^{-3} \mathrm{~m} / \mathrm{s}$. Due to the similarity of the lithological setting, many of the findings from the mentioned studies in other crystalline environments can be transferred to the alpine crystalline zone conditions. Depending on the fracture density and the connectivity of the fracture network, groundwater flow velocities and mean residence times are highly variable. Mean residence times may be in the range of months up to several years or even decades (Kilchmann et al. 2004). The mixing of infiltration water from various events and various residence times lead to a mean mineralisation corresponding to the geochemical situation in the catchment. Rapid changes at the surface do not usually result in significant changes in the water quality and quantity of the springs.

Due to the very low solubility of the silicate minerals of gneiss and granite, the groundwater has a low content of total dissolved solids $(<50 \mathrm{mg} / \mathrm{l})$ (Bender et al. $2001)$ and is slightly acidic or slightly alkaline ( $\mathrm{pH}$ values 6-7.5). The majority of the groundwater is of the $\mathrm{Ca}-\mathrm{Mg}-\mathrm{HCO}_{3}$ or $\mathrm{Ca}-\mathrm{Mg}-\mathrm{HCO}_{3}-\mathrm{SO}_{4}$-water type
(Austrian Geological Survey 2004, Kilchmann et al. 2004; Kralik et al. 2005).

However, completely different hydrochemical compositions were observed in local study areas. Some unique hydrochemical data were documented from the Gotthard Base Tunnel in Switzerland (Bucher et al. 2012) where sodium is the prime cation of most waters, while calcium, potassium, and magnesium occur in low concentrations. Carbonates as well as chloride and sulphate are detected in varying concentrations as anion equivalent. Most of the waters were classified as $\mathrm{Na}_{2}-\mathrm{CO}_{3}$ waters (Seelig and Bucher 2010), which is very uncommon for groundwater from crystalline aquifers.

\section{Abiotic natural tracers in alpine hard rock hydrogeology}

Glynn and Plummer (2005) offer a comprehensive overview of the major developments in groundwater hydrochemistry beginning in the 1950s. They emphasised the hydrochemical facies concept (Back 1960), thermodynamic equilibrium concepts and hydrochemical modelling (e.g. Helgeson 1968, Plummer et al. 1978; Plummer and Busenberg 1982) as milestones in groundwater chemistry.

Groundwater temperature as an easy to measure physical parameter is used in hydrogeology as an indicator for recharge elevation, mean residence times and flow dynamics in mountain catchments (Linan Baena et al. 2009). Unusually high water temperature can indicate a deep groundwater reservoir and geothermal influence (Hilberg and Kreuzer 2013). Generally baseflow components of springs reflect the mean annual temperature of the discharge region, while short-term influences from storm events or snow melt cause seasonal or diurnal variations. Specific electrical conductivity (EC) is a bulk parameter to quantify the total mineralisation of water (physical background is given e.g. by Matsubayashi et al. 1993). EC is controlled mainly by dissolution processes within the aquifer; therefore, the parameter can be used as an indicator for various aquifer lithologies. Due to varying solubility of the mineral phases, carbonate and even more evaporitic aquifers are characterised by highly mineralised groundwater, whereas silicate lithologies contain groundwater with comparably lower EC values (Kilchmann et al. 2004). Particularly in alpine environments, EC variations are good indicators of separate baseflow from event-influenced flow components of springs (e.g. Laudon and Slaymaker 1997).

The major ion composition of groundwater can provide a wide range of information about the aquifer lithology, flow dynamics or anthropogene influences on groundwater quality. A general classification based on the cations calcium, magnesium, sodium, and potassium, and the anions bicarbonate, sulfate and chloride, is given by Piper (1944) and Furtak and 
Langguth (1967). While bicarbonate is the dominant anion species in a carbonatic aquifer, dominance of sulfate or chloride indicates evaporitic influences (gypsum or halite) in the aquifer; particularly in carbonate aquifers such as the NCA in Austria, the $\mathrm{Ca}-\mathrm{Mg}$ ratio of groundwater indicates calcite $(\mathrm{Ca}>\mathrm{Mg})$ or dolomite $(\mathrm{Ca} \approx \mathrm{Mg})$ dominance (Hilberg and Schneider 2011).

Oxygen content, total organic carbon (TOC) and nitrate $\left(\mathrm{NO}_{3}\right)$ are natural tracers indicating fast infiltration and the influence of soil and the unsaturated zone on groundwater quality (Charlier et al. 2012; Mudarra et al. 2014; Quiers et al. 2014). Additionally $\mathrm{NO}_{3}$ is an indicator for agricultural and thus anthropogenic influenced aquifers (Stoewer et al. 2015).

A fundamental overview of hydrochemistry in shallow alpine aquifers is given by Kilchmann et al. (2004). Based on 20 year-long observations at 487 sites along the alpine belt, they found clear evidence of the possibility to classify groundwaters with respect to their alpine unit. They figured out that groundwaters from crystalline, evaporitic, carbonate, molasses or flysch aquifers can be clearly identified by their main or trace elements and the degree of mineralisation.

Aside from major and trace hydrochemical parameters, the use of isotopes has been developed as an important tool in alpine hydrogeology over the last few decades. The stable isotopes of water $\left({ }^{18} \mathrm{O}\right.$ and Deuterium) are sensitive to temperature and, thus, to the elevation and seasonality of precipitation. Maloszewski et al. (2002) describe the identification of flow systems in a karstic-fissured-porous aquifer in the NCA by modelling of the ${ }^{18} \mathrm{O}$ and ${ }^{3} \mathrm{H}$ isotope. Barbieri et al. (2005) used the stable isotope ratios of ${ }^{18} \mathrm{O} /{ }^{16} \mathrm{O},{ }^{2} \mathrm{H} / \mathrm{H}$ and ${ }^{87} \mathrm{Sr} /{ }^{86} \mathrm{Sr}$ to determine the mean elevation of groundwater recharge areas and identify the seasonal influence on recharge in the Gran Sasso karst aquifer. Carbon isotopes $\left({ }^{12} \mathrm{C} /{ }^{13} \mathrm{C}\right.$ ratios) can be used to reconstruct the origin of dissolved carbonate in springs (Chapelle et al. 1988; Telmer and Veizer 1999; Cane and Clark 1999). The sulphur isotopes of spring waters $\left(\mathrm{d}^{34} \mathrm{~S}\right.$ values) provide information about the origin of the dissolved sulphate (e.g. pyrite or evaporites from different periods; Clark and Fritz 1997).

Due to the fact that karst aquifers constitute a main reservoir for drinking water in Austria, karst hydrogeology has a long tradition in the country. Cave research began in the late 19th century (Kraus 1894). Bauer and Zötl (1972) and Christian and Spötl (2010) give an overview of karst research during the last century and the last few decades, respectively. Up to $20 \%$ of Austria's land surface consists of karstified units (Kralik 2001). Alpine foreland basins and intra-alpine basins with important porous aquifers make up less than $40 \%$ of the Austrian land surface. This means that approximately $40 \%$ of Austria is made up of non- or less karstifiable lithologies and fractured hard rock aquifers or hard rock aquitards in mountain terrains; however, published studies on fractured hard rock aquifers in Austria are scarce.

A literature search for hydrogeological studies in Austria in the databases Web of Science/SCI Expanded and GeoRef, in some of the main international hydrogeological journals, in the Austrian Journal of Earth Sciences, and in the journal "Hydrogeologische Beiträge" (Hydrogeological Contributions) was conducted in August 2015. It is highly probable that many unpublished reports focusing on hard rock aquifers do exist; however, the results of the literature search clearly indicate that research on the fractured hard rock aquifers of the Austrian Alps and adjacent regions is significantly underrepresented (Fig. 2).

The articles were distinguished after the main topics they deal with. Five classes were defined: fractured aquifers, karstic aquifers, porous aquifers, surface water including water balance, and other topics (e.g. hydrogeology of landslides, rock glaciers and glacier hydrology, hydrogeology under permafrost conditions, groundwater pollution). Altogether, 18 articles were found that deal with hard rock hydrogeology in the Austrian Alps or adjacent regions. While five articles focus on hydraulic aspects of groundwater flow in fractures (Untersweg and Schwendt 1996; Fasching et al. 2010; Winkler et al. 2010; Perello et al. 2013) or methodology (e.g. Reichl et al. 2001), 12 studies were found that use abiotic groundwater components (major and trace elements or water isotopes) to interpret flow systems. These 12 publications are briefly discussed chronologically in the following. The locations of the study sites are marked in Fig. 1.

The first review on hydrochemical compositions of groundwaters in non-karstified parts of the Austrian Alps was published by Tornquist (1928). He elucidated the possible correlation between ore deposits and mineral and thermal springs in the Austrian Alps with a particular focus on the Gastein thermal springs. The Gastein thermal water regime was of particular interest to Austrian hydrogeologists again in the late 1960s and the early 1970s (Job and Zötl 1969; Job and Mairhofer 1970; Zimmermann and Zötl 1971; Job and Scheminzky 1973). The hydrochemical and isotope data of these deep circulating temperate springs were discussed extensively during this time period (study area 1 in Fig. 1).

The first hydrochemical and isotope investigations in shallow cold and non-salinar groundwater regimes were published in the context of tunnel constructions and the subsequent tunnel inflow (Stundl 1958, study area 2 in Fig. 1; Job and Mutschlechner 1969, study area 3 in Fig. 1; Rampsbacher et al. 1991, study area 4 in Fig. 1). A comprehensive study of hydrogeological and hydrochemical conditions was conducted in the Eiblschrofen Massif in Tyrol (Millen 2003, study area 5 in Fig. 1) where long-term hydrochemical and isotope data of 45 springs in the catchment were used to assign emerging groundwaters to different flow paths and lithologies by 


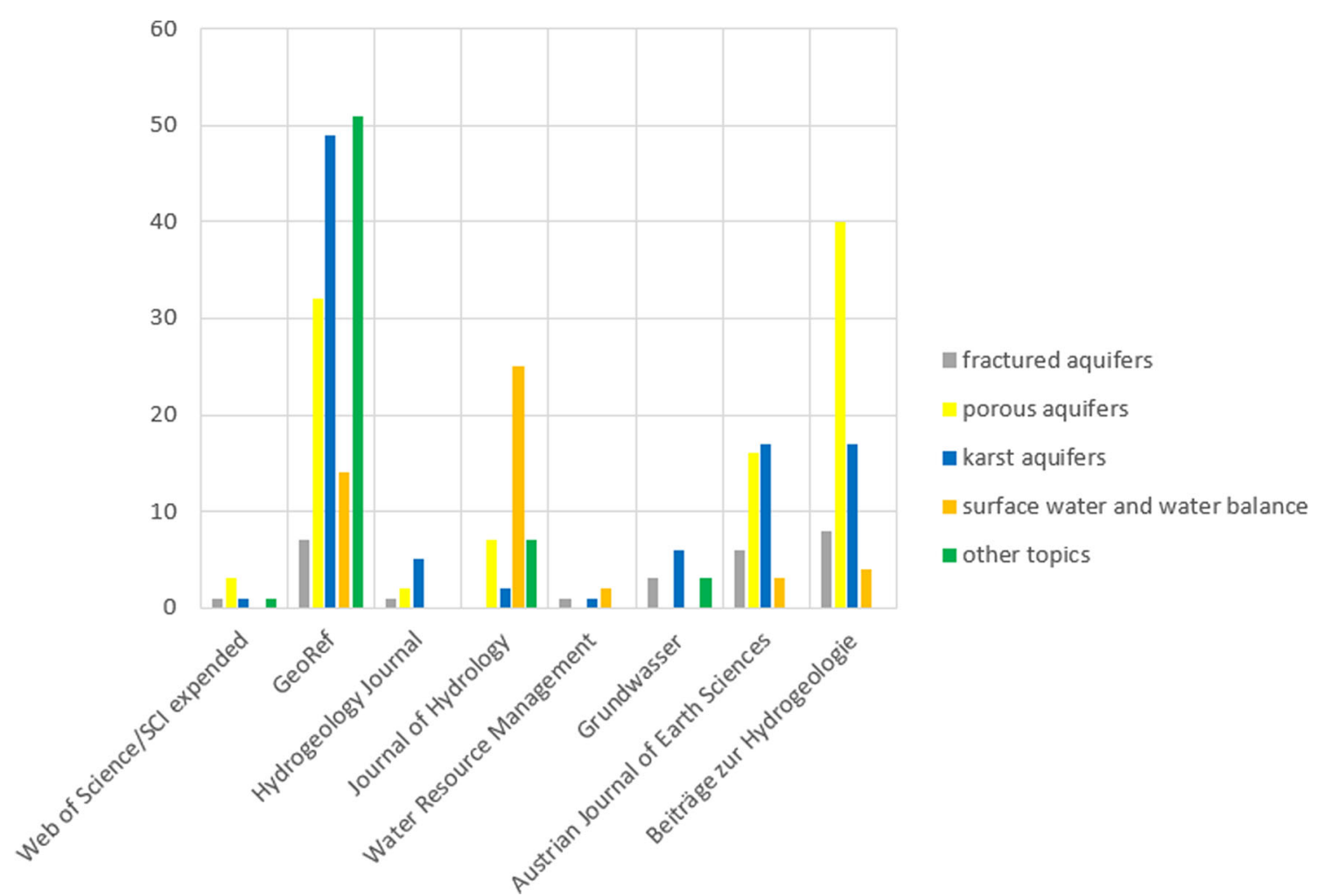

Fig. 2 Published hydrogeological investigations dealing with Austrian study sites. The terms "Austria" and "Hydrogeology" were searched for and the search was conducted in August 2015. The classification of the

defining six water types considering major ions and total mineralisation.

Results from a hydrogeological study in a small catchment in the Styrian Ringkogel area were published by Rank et al. 2003 (study area 6 in Fig. 1). Measurements of the stable isotope composition in spring waters during storm events indicated a three-component flow model consisting of base flow from the fractured aquifer.

The Austrian Geological Survey (2004) developed a database, named GeoHint, which records background values of the main ion concentrations of shallow groundwater from wells, springs, surface runoffs and sediments in Austria. The Hydrochemical Map of Austria was constructed based on this database (Kralik et al. 2005). Both documents include hydrochemical data from the expanded fracture hard rock aquifers and thus provide a valuable base for regional studies.

An example of the investigation of an interesting hydrochemical composition of groundwater from fractured hard rock is documented from granites in the Mühlviertel in Upper Austria (Schubert et al. 2010, study area 7 in Fig. 1). Besides important insights on the sampling requirements, the study showed the correlation between uranium contents of various granites and radon contents of groundwater from different catchments. Although the study is not located within the Austrian Alps but rather in the Austrian part of the Bohemian Massif, it can contribute valuable information about main topics of fractured, karstic, porous aquifers, surface water and others followed after reading the abstract, geological site description and conclusions of each article

hydrochemical properties of the central crystalline zone in the alpine belt since lithology, petrography and thus geochemical properties are comparable - for instance, high radon concentrations are also observed in crystalline landslide material in the Tyrolean Ötz Valley (Purtscheller et al. 1999)

Finally, two studies dealing with the use of $\mathrm{CO}_{2}$ partial pressure and calcite saturation in low-karstifiable settings should be mentioned here. Catchments in the frame region of the Tauern Window in Carinthia and Salzburg, and in the Greywacke zone in Tyrol, were investigated by means of these parameters (Hilberg 2011; Hilberg et al. 2013, study areas 8, 9 and 10 in Fig. 1). Details about these studies are given in section 'Some thoughts about future perspectives'.

\section{Biotic natural tracers in hydrogeology}

It is well known that microbiota (bacteria, fungi and protozoa) play an important role for geological processes such as weathering and mobilizing of mineral constituents (Ehrlich 1998). The fundamental benefits as well as the challenges and problems of the interdisciplinary approach of hydrogeology and microbiology, starting with educating collaborators on methods and principles of the other discipline, were pointed out by Bekins (2000). A general overview of the development of microbiology in groundwater research is given by 
Danielopol and Griebler (2008). Several studies conducted in pristine aquifers showed that microorganisms can enhance or diminish porosity and thus strongly influence the permeability of aquifers (Bennet and Siegel 1987; McMahon and Chapelle 1991). Approximately half of the dissolved inorganic carbon in the groundwater comes directly from microbial metabolism (Chapelle 2000). Microbiology is an intensively studied and already established topic in groundwater pollutant research (e.g. Bradley 2000; Lovely and Anderson 2000; Haack and Bekins 2000; Rüttinger et al. 2006; Marczinek et al. 2008; Mellendorf et al. 2010).

Aside from microbiota, aquifers can be populated by meioor even macroscale fauna (invertebrates as well as vertebrates). Basically, groundwater organisms are classified into three groups: stygobionts, which are highly adapted to groundwater habitats and seemingly not able to exist elsewhere; stygophiles, which are able to live in surface and groundwater; and stygoxenes, which are not able to establish permanent populations in groundwater, but might occasionally be found therein (Gibert et al. 1994).

It is widely known in the hydrogeological community that caves are home to a wide range of higher organisms such as blind fish, gastropods, and amphipods (Humphreys 2009). So far, the inhabitants of porous aquifers are more in the focus of groundwater ecologists than of hydrogeologists. Many studies were conducted on this topic from the biological point of view during the last 20 years. Hancock et al. (2005) and Danielopol and Griebler (2008), give an overview of current ecological groundwater research. Hahn (2009) merges the findings from the last decades and proposes an extended typology of groundwater habitats. Measures of three important abiotic parameters (water temperature, organic content and the oxygen content) were integrated into one index, the so-called groundwater fauna index (GWI). The GWI is considered as a reliable and indicative measure of certain types of groundwater habitats with respect to surface-water/groundwater interaction and exchange processes (low, intermediate, and high) influencing the groundwater fauna. The maturity index (MI; Bongers 1990) considers information on the ecological strategies of organisms. The strategies may range from colonisers (low MI: short generation times, high number of offspring, able to deal with sparse resources and instable habitats, early successional stages) to persisters (high MI: long generation times, low number of offspring, adapted to stable and welldeveloped habitats, later successional stages).

Several studies on groundwater fauna in porous aquifers and surface-groundwater interaction were conducted in the last few years in Germany (e.g. Matzke et al. 2004; Berkhoff et al. 2009; Brielmann et al. 2011; Gutjahr et al. 2013). In Austria, groundwater fauna research is currently restricted to a few study areas in caves and porous aquifers. Cave studies were conducted by Christian and Spötl (2010). Groundwater fauna data from 225 wells and springs were sampled and documented in the vicinity of Salzburg (Priesel-Dichtl 1959, study area (a) in Fig. 1). Groundwater biological sampling campaigns in the alluvial Danube aquifer in eastern Austria were conducted in the 1980s and 1990s (Danielopol and Niederreiter 1987; Danielopol 1989; Niederreiter and Danielopol 1991, study area (b) in Fig. 1). Studies about faunal components of the fractured hard rock aquifers of Austria and to the author's knowledge of other alpine regions are not published to date.

\section{Some thoughts about future perspectives}

\section{Abiotic approach}

Glynn and Plummer (2005) identified still fundamental unsolved problems in groundwater hydrochemistry. From the perspective of an alpine hydrogeologist, one of the shortcomings, particularly concerning fractured aquifers in mountain regions, is the restricted accessibility of sampling points. The hydrogeological interpretation of hydrochemical and isotope data presume long-term and close-meshed data sets of at least one hydrological year. This is necessary with respect to the seasonality of precipitation and temperature and its potential influence on the quality and quantity of the spring discharge; however, springs in high mountain regions are potentially inaccessible due to heavy snowfall and the danger of avalanches for at least half the year. Consequently, the database to determine the hydrogeological characteristics of a fractured aquifer is often fragmentary; hence, data scarcity is a well-known problem in hard rock hydrogeology in mountain regions.

To overcome this problem, a method is required that delivers reliable results within relatively short investigation times during summer. This method must be sensitive to the elevation of infiltration (premise 1) and largely independent of seasonal variations (premise 2).

Main factors of the discussed approach are $\mathrm{CO}_{2}$ partial pressure $\left(\mathrm{pCO}_{2}\right)$ and calcite saturation $\left(\mathrm{SI}_{\text {calc }}\right)$. In the upper soil horizon, $\mathrm{CO}_{2}$ in soil air is stable and in equilibrium with the atmosphere. The $\mathrm{pCO}_{2}$ of soil water is near atmospheric conditions. The system is open with respect to $\mathrm{CO}_{2}$. In deeper parts of the unsaturated zone the $\mathrm{pCO}_{2}$ of soil air increases with respect to the bioactivity in the soil zone. Exchange between soil and atmosphere is hampered and soil water is in equilibrium with ground air conditions. In mountain regions, significant variations in vegetation zones, in soil thickness and in biological activities lead to significant variations in $\mathrm{CO}_{2}$ production. Thus, $\mathrm{pCO}_{2}$ in soil air and water correlates strongly with the elevation of the infiltration area (premise 1: sensitivity to elevation).

Significant variations in the $\mathrm{CO}_{2}$-content on a seasonal as well as diurnal scale within the topsoil air of karst aquifers and surface runoffs are detected as a result of 
temperature and daylight dependent variations of biological activities (Liu et al. 2007; Hayashi et al. 2012). Besides the rapidly influenced topsoil air, ground air $\mathrm{CO}_{2}$ in deeper sections of the unsaturated zone results from transported organic matter and has an important influence on the amount of dissolved $\mathrm{CO}_{2}$ in groundwater and springs. Atkinson (1977) found that $\mathrm{CO}_{2}$-conditions in ground air (deeper sections of the unsaturated zone) are more or less free of seasonal influences. $\mathrm{CO}_{2}$ variations in the soil solution of superficial horizons are reduced in deeper parts of the unsaturated zone. The thicker the unsaturated zone and the soil layer the less pronounced are the seasonal variations in $\mathrm{pCO}_{2}$ of soil solution (and thus of groundwater) throughout the year.

The approach to using $\mathrm{CO}_{2}$ as an indicator for recharge areas has previously been tested only in karst aquifers (Shuster and White 1971, 1972; Fank et al. 1989; Harum et al. 1992; Benischke et al. 1996; Savoy et al. 2011). Due to the correlation of soil thickness and $\mathrm{pCO}_{2}$ one can assume that in fractured aquifers with a soil zone and an unsaturated zone of sufficient thickness, premise 2 (independency of seasonal influences) should be fulfilled as well.

When reaching the watershed, $\mathrm{CO}_{2}$-partial pressure does not vary significantly anymore because diffusion of $\mathrm{CO}_{2}$ through water is slow (Appelo and Postma 2005). Below groundwater level, the system can be considered as more or less closed with respect to $\mathrm{CO}_{2}$. Within the groundwater body, $\mathrm{CO}_{2}$ reacts with the aquifer lithology and varies as a result of $\mathrm{CO}_{2}$-influencing reactions. With respect to the carbonic acid equilibrium (Plummer et al. 1978; Plummer and Busenberg 1982; Hobiger 2015) in aquatic media and soils, the most important $\mathrm{CO}_{2}$-influencing reaction is calcite dissolution or deposition. Calcite dissolution takes place in the aquifer as long as the system is undersaturated with regard to calcite due to high $\mathrm{CO}_{2}$ partial pressure resulting from the previously described soil processes. In contrast, calcite deposition is a consequence of $\mathrm{CO}_{2}$ degassing at spring issues. Since calcite dissolution is not restricted to carbonate settings but is also observed in crystalline environments (Kilchmann et al. 2004), there is nothing to be said against the application of the approach in less or non-karstifiable fractured aquifers. $\mathrm{CO}_{2}$-influencing reactions within the aquifer are considered in regard to the saturation index of calcite $\left(\mathrm{SI}_{\mathrm{cal}}\right)$, which describes the potential for dissolution or deposition of carbonate minerals in the aquatic system. Thus, $\mathrm{pCO}_{2}$ must be seen in context with $\mathrm{SI}_{\mathrm{cal}}$ in order to reconstruct recharge processes. Assuming that premise 2 is appropriate, a single dataset or only a few samples taken in high mountain regions under safe summer conditions should be sufficient for a quick estimation of possible flow paths when processing hydrochemical data in the aforementioned way.
First results from three study sites (study areas 8, 9 and 10 in Fig. 1) in Austria are presented in Hilberg (2011) and Hilberg et al. (2013). In the studied fractured aquifers in mountainous environments (elevations between 800 and $2,500 \mathrm{~m}$ asl), it was possible to define four groups of springs with respect to their $\mathrm{SI}_{\text {calc }} / \mathrm{pCO}_{2}$ ratio. The different groups were assigned to particular flow paths. Distinguished flow paths and the classification are shown in Fig. 3.

The results in the three study sites are plausible from the geological and hydrogeological point of view and the evidence for the functionality of the method is strong; however, the classification has not been validated by means of established hydrogeological methods. Thus, the last step from a scientific theory to a confirmed technique is still missing and further studies concerning geo- and hydrochemical investigations in groundwater, soil and aquifer lithology, isotopic studies $\left(\mathrm{d}^{18} \mathrm{O}\right.$, deuterium, carbon isotopes) and pedological investigations in the test sites are required in future.

\section{Biotic approach}

Notwithstanding the knowledge of biologists about groundwater fauna discussed earlier, it is a surprising experience for most hydrogeologists to learn about the life in groundwater bodies they usually only know well as fluxes of water, abiotic particles, dissolved solids, and heat (Bertrand et al. 2012). Humphreys (2009) presents three major components that are essential for groundwater ecosystems on one side and basic parameters to understanding flow systems on the other- a place to live, oxygen, and food. The requirements of groundwater organisms are strongly related to the geological, hydrological and, hence, hydrogeological conditions. The size and geometry of voids are limiting factors for the maximum size of groundwater animals and control hydraulic conductivity and groundwater dynamics.

The percolation of precipitation through soil and the interaction between surface water and groundwater are processes to deliver oxygen and nutrients into the aquifer and control groundwater temperature; thus, groundwater recharge controls the GWI (Hahn 2009).

Lithology, flow velocity, mean residence times, and circulation depth are the determining factors for physio-chemical properties of groundwater and hence define the living conditions and the ecological strategies defined by the MI (Bongers 1990) for aquifer inhabitants.

The close relationship between groundwater habitats and the hydrogeological settings makes inhabitants optimal indicators of the basic subsurface conditions in porous aquifers as well as in hard rocks with fracture or conduit flow conditions as compiled in Table 2. A theoretical example for the combined approach of hydrogeological investigations and 

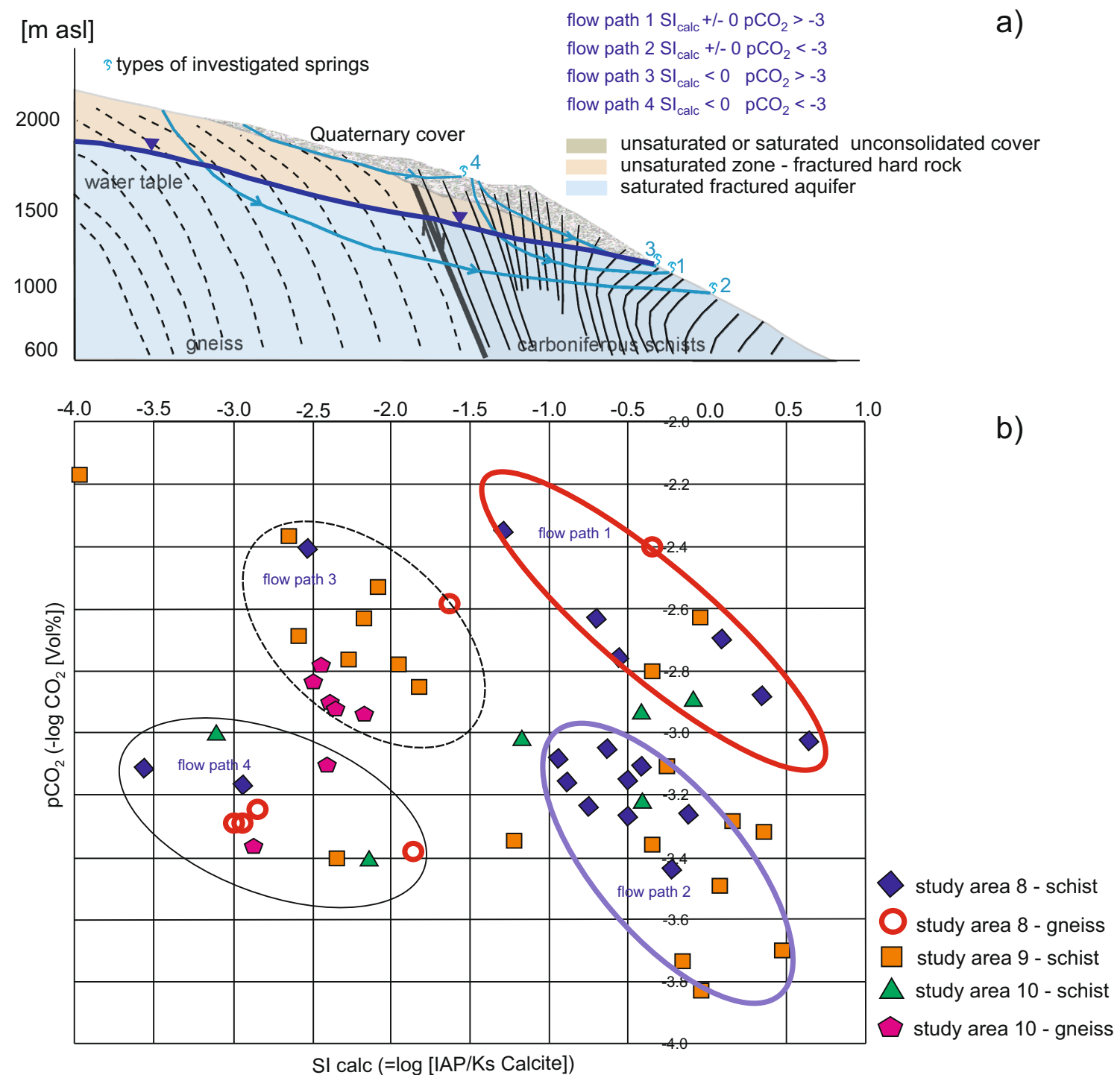

Fig. 3 a Schematic possible flow paths within an alpine fractured aquifer. With regard to the different infiltration areas and percolation depths, four groups of spring waters can be defined with respect to their $\mathrm{SI}_{\text {cald }} / \mathrm{pCO}_{2}$ ratio. b Plotting $\mathrm{SI}_{\text {calc }}$ versus $\mathrm{pCO}_{2}$ in the scatter diagram

groundwater biology is given by Eisendle-Flöckner and Hilberg (2015) and briefly discussed in the following. enables classification of the investigated springs into four groups. Each group indicates the possible flow path visualized in part a (modified after Hilberg et al. 2013)

Referring to the geological and hydrogeological setting introduced for the example in section 'Abiotic approach',
Table 2 Combination of some of the basic hydrogeological attributes of fractured hard rock aquifers with the expected biological setting

\begin{tabular}{llllll}
\hline Hydrogeology & GWI & MI & Share of stygobionts & Size of organisms \\
\hline $\begin{array}{l}\text { Surface-water/ } \\
\text { groundwater interaction }\end{array}$ & Low & Low & High & $\begin{array}{c}\text { Stygobionts }>\text { stygophiles, no } \\
\text { stygoxenes }\end{array}$ & - \\
Hesidence times & Short & High & Low & $\begin{array}{c}\text { Stygobionts }<\text { stygophiles, } \\
\text { stygoxene probable } \\
\text { stygonts }<\text { stygophiles, }\end{array}$ & - \\
& Long & Low & High & $\begin{array}{c}\text { Stygobionts }>\text { stygophiles, no } \\
\text { stygoxenes }\end{array}$ & - \\
Void size & Small & - & - & - & Small \\
& Large & - & - & - & Different-sized \\
organisms
\end{tabular}


Fig. 4 Schematic possible flow paths within an alpine fractured aquifer. With regard to the different infiltration areas and percolation depths, distinct groups of spring waters can be defined with respect to the groundwater fauna patterns. A groundwater observation well in a distinct fractured aquifer helps to identify groundwater habitats in various lithologies (figure modified after Hilberg et al. 2013)

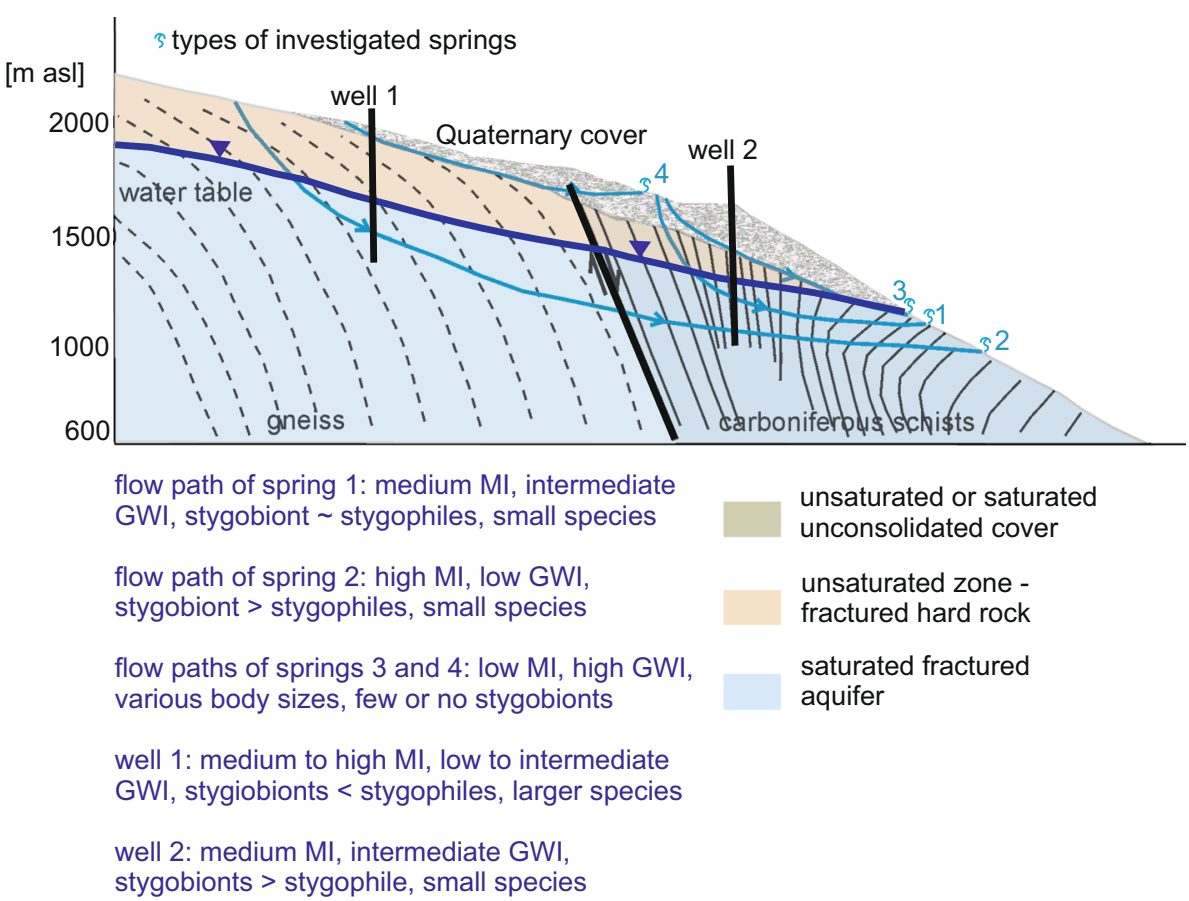

generally different flow regimes can be identified by groundwater fauna patterns (Fig. 4):

- Flow path spring 1:

- Hydrogeology: topographically lower infiltration area, infiltration of oxygen and nutrients from a thick soil zone, circulation in carbon-mica schist, small void sizes, intermediate mean residence times of groundwater

- Groundwater biology: medium GWI, medium MI, stygobionts and stygophiles, some stygoxene probable, small species

- Flow path spring 2:

- Hydrogeology: topographically higher infiltration area with low input of nutrients from the high mountain surface, circulation in gneiss as well as in carbon-mica schist, small void sizes, long mean residence times

- Groundwater biology: high MI and low GWI because of longest mean residence times, stygobionts prevail, small species

- Flow path springs 3 and 4:

- Hydrogeology: circulation in unconsolidated cover, emerging without any contact to the hard rock aquifer, short mean residence times

- Groundwater biology: low MI, high GWI (spring 3 higher than spring 4), few or no stygobionts, stygophiles prevail, stygoxene common, organisms of various size
Because the wells are established within distinct hydrological settings and the flow paths represent different combinations thereof, different faunal structures are expected for the wells in Fig. 4:

- Well 1 within gneiss complex: intermediate to high MI, low to intermediate GWI, stygobiont< $<$ stygophiles, larger species prevail because of comparably bigger open fractures in gneiss lithology

- Well 2 within carbon-mica schist: medium MI, medium GWI, stygobionts > stygophiles, small species prevail due to small and secondarily refilled open voids

Based on the ideas of this theoretical example the implementation of biotic analysis in hard rock hydrogeology requires a systematic survey of habitats in several study sites with different but typical and well-known conditions with regard to lithology, flow dynamics, hydrochemistry, and recharge conditions.

From the biological perspective, some shortcomings and uncertainties in the use of groundwater fauna as hydrogeological tracers originate in endemism and scarcity of the investigated taxa. Currently crustaceans with restricted geographical ranges represent the major target in groundwater research. The establishment of more general principles in groundwater typology require the implementation of further taxa that are less prone to endemism; for instance, the group of free living groundwater nematodes might help to overcome these shortcomings (Eisendle-Flöckner and Hilberg 2015). 


\section{Conclusions}

This review gives an overview of the state of the art in the use of natural tracers in alpine hard rock hydrogeology with a particular focus on the Austrian Alps region. The predominance of fractured hard rock aquifers arranged in folded and thrusted nappes of various lithology, elevation differences of several thousands of meters, the function as continental divide and shortcomings in hydrogeological methodology for this special environment are characteristic for alpine type mountain regions and make the European Alps a suitable representative for mountain hydrogeology. A long history of geological research in the comparably small-scale structured (less than $200 \mathrm{~km}$ in north-south direction) mountain belt provides a solid foundation for basic hydrogeological research. Moreover, the densely populated inner alpine regions and a network of aquifer penetrating infrastructural facilities (streets, tunnels, pipelines) require a detailed knowledge of aquifer characteristics at least on a local scale. However, compared to the comprehensive international literature dealing with the interpretation of physio-chemical parameters and isotopes in spring waters, similar publications about the Austrian Alps hydrogeology in international journals are scarce.

A comprehensive set of abiotic natural tracers such as water temperature, electrical conductivity, the major ion composition, and oxygen-, TOC- and nitrate-content has been established in the last decades and is used also for mountain aquifers. The aquatic species concept, thermodynamics and hydrochemical modelling tools improved the toolbox for the interpretation of hydrochemical data. However, one general problem of the use natural tracers in mountain hydrogeology is the seasonality of these parameters and the restricted accessibility of sampling points in high mountain regions during base flow conditions in winter. Hence, data sets are often fragmentary and interpretations are afflicted with uncertainties. The example presented, to use hydrochemical modelling tools and particularly $\mathrm{CO}_{2}$ partial pressure combined with calcite saturation as a seasonally stable indicator for mean recharge elevations in mountain catchments, might help to overcome this particular problem.

Meiofaunal organisms have been introduced here as potential biological natural tracers in hydrogeology. Knowledge about groundwater organisms have not yet found a way into hydrogeological research. Studies on groundwater fauna were conducted by biologists mainly within porous aquifers with a main focus on surface-water/groundwater interaction, widely neglecting further hydrogeological features. Biological studies on fractured hard rock aquifers are completely missing to date. However, existing biological concepts such as the groundwater fauna index or the maturity index as well as the classification of organisms with regard to their preferred habitat might be promising approaches for interdisciplinary studies in all kinds of aquifers.
For the implementation of both, abiotic as well as biotic natural tracers, in a holistic and interdisciplinary approach, extensive further investigations and the willingness of hydrogeologists and biologists to cooperate are required. With regard to the existing detailed geological knowledge, the small-scaled structure and the good infrastructural development the Austrian Alps provide best conditions to act as a representative model region to improve the toolbox of mountain hydrogeologists. Future developments in this direction presume a greater emphasis of hard rock hydrogeology in students' education (geological as well as engineering studies) and the increased willingness of Austrian hydrogeologist to discuss their findings on an international level.

Acknowledgements Open access funding provided by Paris Lodron University of Salzburg. I greatly acknowledge the constructive suggestions by Maurizo Barbieri, one anonymous reviewer and the associate editor of Hydrogeology Journal.

Open Access This article is distributed under the terms of the Creative Commons Attribution 4.0 International License (http:// creativecommons.org/licenses/by/4.0/), which permits unrestricted use, distribution, and reproduction in any medium, provided you give appropriate credit to the original author(s) and the source, provide a link to the Creative Commons license, and indicate if changes were made.

\section{References}

Andrews JN, Goldbrunner JE, Darling WG, Hooker PJ, Wilson GB, Youngman MJ, Eichinger L, Rauert W, Stichler W (1985) A radiochemical, hydrochemical and dissolved gas study of groundwaters in the Molasse basin of Upper Austria. Earth Planet Sci Lett 73:317332

Appelo CAJ, Postma D (2005) Geochemistry, groundwater and pollution, 2nd edn. Balkema, Leiden, The Netherlands

Atkinson TC (1977) Carbon dioxide in the atmosphere of the unsaturated zone: an important control of groundwater hardness in limestones. J Hydrol 35:111-123

Austrian Geological Survey (2004) Geohint, Österreichweite Abschätzung von regionalisierten hydrochemischen Hintergrundgehalten in oberflächennahen Grundwasserkörpern auf der Basis geochemischer und wasserchemischer Analysedaten zur Umsetzung der Wasserrahmenrichtlinie 2000/60/EG - Endbericht [GeoHint, Austrian wide estimation of regionalised background values in shallow groundwater bodies on the basis of geochemical and hydrochemical data for the implementation of the European water directive: final report]. Austrian Geological Survey, Vienna

Austrian Ministry of Life (2012) Hydrografisches Jahrbuch von Österreich 2012, 120. Band [Hydrographical annual report of Austria 2012, vol 120] Hydrographical Survey of Austria, Vienna

Back W (1960) Origin of hydrochemical facies of groundwater in the Atlantic Coastal Plain. In: Proceedings of 21st International Geological Congress, Copenhagen, 1960, vol 1, pp 87-95

Bakalowicz M (2005) Karst groundwater: a challenge for new resources. Hydrobiol J 13:148-160. doi:10.1007/s10040-004-0402-9

Barbieri M, Boschetti T, Petitta M, Tallini M (2005) Stable isotope $\left({ }^{2} \mathrm{H}\right.$, ${ }^{18} \mathrm{O}$ and ${ }^{87} /{ }^{86} \mathrm{Sr}$ ) and hydrochemistry monitoring for groundwater hydrodynamics in a karst aquifer (Gran Sasso, central Italy). Appl Geochem 20:2063-2081. doi:10.1016/j.apgeochem.2005.07.008 
Bauer F, Zötl J (1972) Karst of Austria. In: Herak M, Springfield VT (eds) Karst: important karst regions of the northern hemisphere. Elsevier, Amsterdam, pp 225-265

Beatrizotti G (1996) Cantone Ticino: evaluazione della permeabilita delle rocce [Canton Ticino: evaluation of rocks permeability]. In: Rapp di lav dell'Istituto della Repubb e Cantone del Ticino. Dipdel Territ, Div pianif territ, Bellinzona, Italy, $17 \mathrm{pp}$

Bekins B (2000) Preface: groundwater and microbial processes. Hydrobiol J 8:2-3

Bender S, Einsiedl F, Wohnlich S (2001) Scheme for development of monitoring networks for springs in Bavaria Germany. Hydrobiol J 9:208-216. doi:10.1007/s100400124

Benischke R, Harum T, Leditzky H (1996) Berechnung von KarbonatKohlensäure-Gleichgewichten: ein Hilfsmittel zur Charakterisierung der Hydrodynamik und Herkunft von Karstwässern [Calculation of carbon-acid equilibrium to characterise hydrodynamic and origin of karst groundwater]. Mitt Österr Geol Ges 87:37-46

Bennet PC, Siegel DI (1987) Increased solubility of quartz in water due to complexation by dissolved organic compounds. Nature 326:684 687

Berge TB, Veal SJ (2005) Structure of the alpine foreland, Tectonics 24, TC 5011. doi:10.1029/2003TC001588

Berkhoff SE, Bork J, Hahn HJ (2009) Grundwasserfauna als Indikator für Oberflächenwasser-Grundwasser-Interaktionen im Bereich einer Uferfiltratanlage [Groundwater fauna as an indicator of surface water-groundwater interactions at a riverbank filtration site]. Grundwasser 14:3-20. doi:10.1007/s00767-008-0095-4

Bertrand G, Goldscheider N, Gobat J-M, Hunkeler D (2012) Review: from multi-scale conceptualization to a classification system for inland groundwater-dependent ecosystems. Hydrobiol J 20:5-25. doi: 10.1007/s10040-011-0791-5

Bongers T (1990) The maturity index: an ecological measure of environmental disturbance on nematode species composition. Oecologia 83:14-19. doi:10.1007/BF00324627

Bradley PM (2000) Microbial degradation of chloroethenes in groundwater systems. Hydrobiol J 8:104-111

Brielmann H, Lueders T, Schreglmann K, Ferraro F, Avramov M, Hammerl V, Blum P, Bayer P, Griebler C (2011) Oberflächennahe Geothermie und ihre potenziellen Auswirkungen auf Grundwasserökosysteme [Shallow geothermal energy usage and its potential impacts on groundwater ecosystems]. Grundwasser 16:77-91. doi:10.1007/s00767-011-0166-9

Bucher K, Stober I, Seelig U (2012) Water deep inside the mountains: unique water samples from the Gotthard rail base tunnel Switzerland. Chem Geol 334:240-253. doi:10.1016/j.chemgeo. 2012.10.031

Caine JS, Evans JP, Forster CB (1996) Fault zone architecture and permeability structure. Geology 24(11):1025-1028

Cane G, Clark ID (1999) Tracing ground water recharge in an agricultural watershed with isotopes. Ground Water 37(1):133-139

Chapelle FH (2000) The significance of microbial processes in hydrogeology and geochemistry. Hydrogeol J 8:41-46

Chapelle FH, Morris JT, McMahon PB, Zelibor JL (1988) Bacterial metabolism and the del-13C composition of groundwater Floridan aquifer, South Carolina. Geology 16:117-121

Charlier J-B, Betrand C, Mudry J (2012) Conceptual hydrogeological model of flow and transport of dissolved organic carbon in a small Jura karst system. J Hydrol 460-461:52-64. doi:10.1016/j.jhydrol. 2012.06.043

Christian E, Spötl C (2010) Karst geology and cave fauna of Austria: a concise review. Int J Speleol 39(2):71-90

Clark I, Fritz P (1997) Environmental isotopes in hydrogeology. Lewis, New York

Danielopol DL (1989) Groundwater fauna associated with riverine aquifers. J N Am Benthol Soc 8(1):18-35
Danielopol DL, Griebler C (2008) Changing paradigms in groundwater ecology: from the "living fossils tradition" to the "new groundwater ecology". Int Rev Hydrobiol 93(4-5):565-577. doi:10.1002/iroh. 200711045

Danielopol DL, Niederreiter R (1987) A sampling device for groundwater organisms and oxygen measurement in multi-level monitoring wells. Stygologia 3(3):589-597

Dewandel B, Marechal JC, Bour O, Ladouche B, Ahmend S, Chandra S, Pauwels H (2011) Upscaling and regionalizing hydraulic conductivity and effective porosity at watershed scale in deeply weathered crystalline aquifers. J Hydrol 416-417:83-97

Ehrlich HL (1998) Geomicrobiology: its significance for geology. Earth Sci Rev 45:45-60

Eisendle-Flöckner U, Hilberg S (2015) Hard rock aquifers and free-living nematodes: an interdisciplinary approach on two widely neglected components in groundwater research. Ecohydrology 8:368-377. doi:10.1002/eco.1516

Fank J, Harum T, Leditzky H-P, Stromberger B, Zojer H (1989) Nitratbelastung des Grundwassers im nördlichen Leibnitzer Feld (Steiermark) [Nitrate contamination of groundwater in the northern Leibnitz aquifer). Steir Beitr Hydrogeol 40:5-48

Fasching A, Vanek R, Stadlmann T, Reichl P, Domberger G, Forstinger G, Wagner OK (2010) New Semmering base tunnel: the investigation program 2008/2009 and the knowledge gained in the areas of geology, hydrogeology and geotechnical engineering. Geomechan Tunnelling 3(2):119-129. doi:10.1002/geot.201000010

Furtak H, Langguth HR (1967) Zur hydrochemischen Kennzeichnung von Grundwässern und Grundwassertypen mittels Kennzahlen [Towards hydrochemical identification of groundwater and types of groundwater by means of indices]. Mem IAH Cong 1965:86-96

Gargini A, Vincenzi V, Piccini L, Zuppi GM, Canuti P (2008) Groundwater flow systems in turbidites of the northern Apennines (Italy): natural discharge and high speed rail way tunnel drainage. Hydrogeol J 16:1577-1599. doi:10.1007/s10040-008-0352-8

Gattinger T (1980) Hydrogeologie [hydrogeology]. In: Oberhauser R (1980) Der geologische Aufbau Österreichs [The geological composition of Austria]. Geologische Bundesanstalt, Vienna, pp 580 594

Gibert J, Stanford JA, Dole-Olivier M-J, Ward JH (1994) Basic attributes of groundwater ecosystems and prospects for research. In: Gibert J, Danielopol DL, Stanford JA (eds) Groundwater ecology. Academic, San Diego, pp 8-42

Glynn PD, Plummer LN (2005) Geochemistry and the understanding of groundwater systems. Hydrogeol J 13:263-287. doi:10.1007/ s10040-004-0429-y

Goeppert N, Goldscheider N, Scholz H (2011) Karst geomorphology of carbonatic conglomerates in the Folded Molasse zone of the Northern Calcareous Alps (Austria/Germany). Geomorphology 130:289-298. doi:10.1016/j.geomorph.2011.04.011

Gutjahr S, Bork J, Hahn HJ (2013) Grundwasserfauna als Indikator für komplexe hydrogeologische Verhältnisse am westlichen Kaiserstuhl [Groundwater fauna as an indicator for complex hydrogeological conditions in the western Kaiserstuhl]. Grundwasser 18:173-184. doi:10.1007/s00767-013-0227-3

Haack S, Bekins B (2000) Microbial populations in contaminated plumes. Hydrogeol J 8:63-76

Hahn HJ (2009) A proposal for an extend typology of groundwater habitats. Hydrogeol J 17:77-81. doi:10.1007/s10040-008-0363-5

Hancock PJ, Boulton AJ, Humphreys WF (2005) Aquifers and hyporheic zones: towards an ecological understanding of groundwater. Hydrogeol J 13:98-111. doi:10.1007/s10040-004-0421-6

Harum T, Zojer H, Leditzky R, Benischke R, Stichler W, Trimborn P, Rank D, Rainer V (1992) Long-term investigations with natural tracers. In: Behrens et al (eds) Investigations with natural and artificial tracers in the karst aquifer of the Lurbach system (PeggauTanneben-Semriach, Austria). Steir Beitr Hydrogéol 43:9-158 
Hayashi M, Vogt T, Mächler L, Schirmer M (2012) Diurnal fluctuations of electrical conductivity in a pre-alpine river: effects of photosynthesis and groundwater exchange. J Hydrol 450-451:93-104. doi: 10.1016/j.hydrol.2012.05.020

Helgeson HC (1968) Evaluation of irreversible reactions in geochemical processes involving minerals and aqueous solutions. Geochim Cosmochim Acta 34:569-592

Hilberg S (2011) Anwendung hydrochemischer Modellrechnungen zur Bestimmung von Infiltrationsgebieten: Fallbeispiel Reißeck, (Oberkärnten, Österreich) [Use of hydrochemical modelling for determination of infiltration areas: case study Reißeck (Upper Carinthia, Austria)]. Grundwasser 16:25-36. doi:10.1007/s00767010-0158-1

Hilberg S, Kreuzer M (2013) Identification of a deep flow system in a dolomitic aquifer: case study Wimmerbauern Spring, Bad Ischl. AJES 106(1):16-25

Hilberg S, Schneider JF (2011) The aquifer characteristics of the dolomite formation: a new approach for providing drinking water in the northern calcareous Alps region in Germany and Austria. Water Resour Manag 25:2705-2729. doi:10.1007/s11269-011-9834-x

Hilberg S, Brandstätter J, Glück D (2013) $\mathrm{CO}_{2}$ partial pressure and calcite saturation in springs: useful data for identifying infiltration areas in mountainous environments. Environ Sci: Processes Impacts 15: 823-832. doi:10.1039/c3em30973h

Hobiger G (2015) Kohlendioxid in Wasser mit Alkalinität: Berechnung und graphische Darstellung der chemischen Gleichgewichte [Carbondioxide in water with alkalinity: calculation and graphical representation of chemical equilibrium]. Springer Spektrum, Heidelberg, Germany

Humphreys WF (2009) Hydrogeology and groundwater ecology: does each inform the other? Hydrogeol J 17:5-21. doi:10.1007/s10040008-0349-3

Job C, Mairhofer J (1970) Der Tritiumgehalt der Kalt- und Warmwässer im Gasteiner Raum [The tritium content of cold and thermal water in Gastein]. Steir Beitr Hydrogeol 22:167-188

Job C, Mutschlechner G (1969) Zur Geochemie der Wässer im Tauerntunnel [Towards the geochemistry of the inflow into the Tauern Tunnel]. Steir Beitr Hydrogeol 21:117-128

Job C, Scheminzky (1973) Der Kaltwasseranteil in den Thermalquellen von Badgastein [The share of cold water in the thermal springs of Badgestein]. Steir Beitr Hydrogeol 25:117-126

Job C, Zötl J (1969) Zur Frage der Herkunft des Gasteiner Thermalwassers [Towards the origin of the Gastein thermal water]. Steir Beitr Hydrogeol 21:51-115

Kilchmann S, Waber HN, Parriaux A, Bensimon M (2004) Natural tracers in recent groundwaters from different alpine aquifers. Hydrogeol J 12:643-661. doi:10.1007/s10040-004-0366-9

Kralik M (2001) Strategie zum Schutz der Karstwassergebiet in Österreich [Strategy for the protection of karst regimes in Austria]. Report 198, Umweltbundesamt, Vienna

Kralik M, Zierzitz I, Grath J, Vincze G, Philippitsch R, Pavlik H (2005) Hydrochemische Karte Österreichs [Hydrochemical Map of Austria]. Report 269, Umweltbundesamt, Vienna

Kraus F (1894) Höhlenkunde: Wege und Zweck der Erforschung unterirdischer Räume [Cave research: methods and purpose of research in underground voids]. Gerold, Vienna

Lachassagne P, Pinault J-L, Laporte P (2001) Radon 222 emanometry: a relevant methodology for water well siting in hard rocks. Water Resour Res 37:333-341

Lauber U, Goldscheider N (2014) Use of artificial and natural tracers to assess groundwater transit-time distribution and flow systems in a high-alpine karst system (Wetterstein Mountains, Germany). Hydrogeol J 22:1807-1824. doi:10.1007/s10040-014-1173-6

Laudon H, Slaymaker O (1997) Hydrograph separation using stable isotopes, silica and electrical conductivity: an alpine example. J Hydrol 201:82-101
Linan Baena C, Andreo B, Mudry J, Carrasco Cantos F (2009) Groundwater temperature and electrical conductivity as tools to characterize flow pattern in carbonate aquifer: the Sierra de las Nieves karst aquifer, southern Spain. Hydrogeol J 17:843-853. doi:10.1007/s10040-008-0395-x

Liniger H, Weingartner R, Grosjean M (1998) Mountains of the world: water towers for the 21st century. Haupt, Bern, Switzerland

Liu Z, Li Q, Sun H, Wang J (2007) Seasonal, diurnal and storm-scale hydrochemical variations of typical epikarst springs in subtropical karst areas of SW China: soil $\mathrm{CO}_{2}$ and dilution effects. J Hydrol 337: 207-223. doi:10.1016/j.hydrol.2007.01.034

Lovely DR, Anderson RT (2000) Influence of dissimilatory metal reduction on fate of organic and metal contaminants in the surface. Hydrogeol J 8:77-88

Maloszewski P, Stichler W, Zuber A, Rank D (2002) Identifying the flow systems in a karstic-fissured-porous aquifer, the Schneealpe, Austria by modelling of environmental ${ }^{18} \mathrm{O}$ and ${ }^{3} \mathrm{H}$ isotopes. J Hydrol 256 : 48-59

Marczinek S, Schäfer W, Pfeiffer S (2008) Identifizierung und Quantifizierung natürlicher Abbauprozesse in einem mit chlorethenen kontaminierten Grundwasserleiter [Identification and quantification of natural degradation processes in an aquifer contaminated with chlorinate ethenes]. Grundwasser 2006(3):207-216. doi: 10.1007/s00767-006-0146-7

Masset O, Loew S (2010) Hydraulic conductivity distribution in crystalline rocks, derived from inflows to tunnels and galleries in the central Alps Switzerland. Hydrogeol J 18:863-891. doi:10.1007/ s10040-009-0569-1

Matsubayashi U, Velasquez GT, Takagi F (1993) Hydrograph separation and flow analysis by specific electrical conductance of water. J Hydrol 152:179-199

Matzke D, Hahn HJ, Ramstöck A, Rother K (2004) Bewertung von altlasten im Grundwasser anhand der Meiofaunagemeinschaften: erste Ergebnisse [Assessment of contaminated groundwater sites using meiofaunal assemblage patterns: first results]. Grundwasser 2005:25-34. doi:10.1007/s00767-005-0067-x

McMahon PB, Chapelle FH (1991) Microbial production of organic acids in aquitard sediments and its role in aquifer geochemistry. Nature 349:233-235

Mellendorf M, Huber-Humer M, Gamperling O, Huber P, Gerzabek MH, Watzinger A (2010) Characterisation of microbial communities in relation to physical-chemical parameters during in situ aeration of waste material. Waste Manag 30:2177-2184. doi:10.1016//j. wasman.2010.04.023

Meybeck M, Green P, Vörösmarty C (2001) A new typology for mountains and other relief classes. Mt Res Dev 21:34-45

Millen BMJ (2003) Aspects of the hydrogeology of a mining region with a focus on the antimony content of the spring-water, Eiblschrofen Massif, Schwaz, Tyrol, Austria. Mitt Österr Geol Ges 94:139-156

Mudarra M, Andreo B, Barber JA, Mudry J (2014) Hydrochemical dynamics of TOC and $\mathrm{NO}_{3}{ }^{-}$contents as natural tracers of infiltration in karst aquifers. Environ Earth Sci 71:507-523. doi:10.1007/s12665013-2593-7

Neumann SP (2005) Trends, prospects and challenges in quantifying flow and transport through fractured rocks. Hydrogeol J 13:124-147. doi: 10.1007/s10040-004-0397-2

Niederreiter R, Danielopol DL (1991) The use of mini-videocameras for the description of groundwater habitats. Mitt Hydrogr Dienst Österr 65-66:85-89

Perello P, Baietto A, Burger U, Skuk S (2013) Excavation of the AicaMules pilot tunnel for the Brenner base tunnel: information gained on water inflows in tunnels in granitic massifs. Rock Mech Rock Eng 47:1049-1071. doi:10.1007/s00603-013-0480-x

Piper AM (1944) A graphic procedure in the geochemical interpretation of water analysis. Eos Trans AGU 25:914-928 
Plan L, Decker K, Faber R, Wagreich M, Grasemann B (2008) Karst morphology and groundwater vulnerability of high alpine karst plateaus. Environ Geol 58:285-297. doi:10.1007/s00254-008-1605-5

Plummer LB, Busenberg E (1982) The solubility of calcite, aragonite and vaterite in $\mathrm{CO}_{2}-\mathrm{H}_{2} \mathrm{O}$ solutions between 0 and $90{ }^{\circ} \mathrm{C}$, and an evaluation of aqueous model for the system $\mathrm{CaCO}_{3}-\mathrm{CO}_{2}-\mathrm{H}_{2} \mathrm{O}$. Geochim Cosmochim Acta 46:1011-1040

Plummer LN, Wigley TML, Parkhurst DL (1978) The kinetics of calcite dissolution in $\mathrm{CO}_{2}$-water systems at $5^{\circ}$ to $60^{\circ}$ and 0.0 to $1.0 \mathrm{~atm}$ $\mathrm{CO}_{2}$. Am J Sci 278:179-216

Pochon A, Tripet J-P, Kozel R, Meylan B, Sinreich M, Zwahlen F (2008) Groundwater protection in fractured media: a vulnerability-based approach for delineating protection zones in Switzerland. Hydrogeol J 16:1267-1281. doi:10.1007/s10040-008-0323-0

Priesel-Dichtl G (1959) Die Grundwasserfauna im salzburger Becken und im anschließenden Alpenvorland [Groundwater fauna in the Salzburg basin and the nearby alpine foreland]. Arch Hydrobiol 55(3):281-370

Purtscheller F, Stingl V, Tessadri R, Mair V, Pirchl T, Sieder G, Brunner P, Schneider P, Ennemoser O (1999) Geologisch-petrographische Ursachen der Radonaniomalie in Umhausen (Tirol) [Geological-petrographical reason for the radon anomaly in Umhausen (Tyrol)]. Mitt Österr Geol Ges 88:7-14

Quiers M, Batiot-Guilhe C, Bicalho CC, Perrette Y, Seidel J-L, Van Exter $S$ (2014) Characterisation of rapid infiltration flows and vulnerability in a karst aquifer using decomposed fluorescence signal of dissolved organic matter. Environ Earth Sci 71:553-561. doi:10.1007/ s12665-013-2731-2

Rampsbacher P, Riepler F, Zojer H, Stichler W (1991) Hydrogeologie des Förolacher Stollens, Gailtaler Alpen (Kärnten) [Hydrogeology of the Förolacher Gallery, Gailtal Alps (Carinthia)]. Steir Beitr Hydrogeol 42:9-60

Rank D, Häusler H, Papesch W (2003) Modellvorstellung zur Abflussentstehung bei Starkregenereignissen im kristallinen Randgebirge: Erkenntnisse aus Isotopenuntersuchungen [Conceptual model of runoff generation during storm events in the crystalline mountains of eastern Styria (Austria), based on isotopehydrological investigations]. Mitt Österr Geol Ges 93:139-159

Rantitsch G, Judik K (2009) Alpine metamorphism in the central segment of the Western Greywacke zone (Eastern Alps). Geol Carpath 60(4): 319-329. doi:10.2478/v10096-009-0023-2

Rehrl C, Birk S (2010) Hydrogeological characterisation and modelling of spring catchments in a changing environment. AJES 103(2):106117

Reichl P, Probst G, Schippek E, Goldschmidt F, Riepler F (2001) Initial hydrogeological and hydrological field investigations for the Koralm Tunnel. Felsbau 19(6):37-40

Rüttinger S, Breiter R, Hirsch K, Alejandro M, Avila S, Tonschall HJ, Neeße T, Bayer M (2006) Natural Attenuation: Untersuchungen an einem LCKW kontaminierten Altdeponiestandort [Natural attenuation: investigations of an abandoned landfill contaminated by chlorinated hydrocarbons]. Grundwasser 2006(3):184-193. doi:10. 1007/s00767-006-0144-9

Savoy L, Surbeck H, Hunkeler D (2011) Radon and $\mathrm{CO}_{2}$ as natural tracers to investigate the recharge dynamics of karst aquifers. J Hydrol 406:148-157. doi:10.1016/j.jhydrol.2011.05.031

Schönlaub HP (1980) Die Grauwackenzone [The Greywacke zone). In: Oberhauser R (1980) Der geologische aufbau Österreichs [The geological composition of Austria]. Geologische Bundesanstalt, Vienna, pp 265-289

Schubert G (2000) Water resources: drinking water. Mitt Österr Geol Ges $92 \cdot 295-311$
Schubert G (2003) Hydrogeologische Karte der Republik Österreich 1: 500.000 [Hydrogeological Map of Austria 1:500.000]. Geological Survey of Austria, Vienna

Schubert G, Alletsgruber I, Finger F, Gasser V, Hobiger G, Lettner H (2010) Radon im Grundwasser des Mühlviertels (Oberösterreich) [Radon in the groundwater of Mühlviertel (Upper Austria)]. Grundwasser 15:33-42. doi:10.1007/s00767-009-0127-8

Seelig U, Bucher K (2010) Halogens in water from the crystalline basement of the Gotthard rail base tunnel (Central Alps). Geochim Cosmochim Acta 74:2581-2595. doi:10.1016/j.gca.2010.01.030

Shuster ET, White WB (1971) Seasonal fluctuations in the chemistry of limestone springs: a possible means for characterizing carbonate aquifers. J Hydrol 14:93-128

Shuster ET, White WB (1972) Source areas and climatic effects in carbonate groundwaters determined by saturation indices and carbon dioxide pressures. Water Resour Res 8(4):1067-1073

Stoewer MM, Knöller K, Stumpp C (2015) Tracing freshwater nitrate sources in pre-alpine groundwater catchments using environmental tracers. J Hydrol 524:753-767. doi:10.1016/j.jhydrol.2015.03.022

Stundl K (1958) Der Chemismus von Quellwässern aus dem PlabutschKollerbegrzug bei Graz [The chemistry of spring water from the Plabutsch-Kollerberg Massif near Graz]. Steir Beitr Hydrogeol 8-9

Telmer K, Veizer J (1999) Carbon fluxes, $p \mathrm{CO}_{2}$ and substrate weathering in a large northern river basin, Canada: carbon isotope perspectives. Chem Geol 159:61-86

Thiele O (1980) Das Tauernfenster [The Tauern Window]. In: Oberhauser R (1980) Der geologische aufbau Österreichs [The geological composition of Austria]. Geologische Bundesanstalt, Vienna, pp 300314

Tornquist A (1928) Mineralquellen (Thermen) und Minerallagerstätten in den Ostalpen [Mineral springs (thermal springs) and mineral deposits in the eastern Alps]. Mitt Geol Ges Wien 21:15-23

Toth J (1999) Groundwater as a geological agent: an overview of the causes, processes and manifestations. J Hydrol 7:1-14

Untersweg T, Schwendt A (1996) Blockgletscher und Quellen in den niederen Tauern [Rock glaciers and springs in the Lower Tauern]. Mitt Österr Geol Ges 87:47-56

Vigna B, Banzato C (2015) The hydrogeology of high-mountain carbonate areas: an example of some alpine systems in Southern Piedmont (Italy). Environ Earth Sci 74:267-280. doi:10.1007/s12665-0154308-8

Viviroli D, Dürr HH, Messerli B, Meybeck M Weingartner R (2007) Mountains of the world, water towers for humanity: typology, mapping, and global significance. Water Resour Res 43:W07447. doi: 10.10.29/2006WR005653

Wagreich M, Pavlishina P, Malata E (2006) Biostratigraphy of the lower red shale interval in the Rhenodanubian Flysch Zone of Austria. Cretaceous Res 27 (6):743-753. doi:10.1016/j.cretres.2006.01.002

Welch LA, Allen DM (2014) Hydraulic conductivity characteristics in mountains and implications for conceptualising bedrock groundwater flow. Hydrogeol J 22:1003-1026. doi:10.1007/s10040-0141121-5

Winkler G, Kurz W, Hergarten S, Kiechl E (2010) Hydraulische Charakterisierung von Störungskernzonen in kristallinen Festgesteinen am Beispiel der Talhof-Störung (Ostalpen) [Hydraulic characterisation of core zones in crystalline hard rocks at the Talhof Fault (Eastern Alps)]. Grundwasser 15:59-68. doi:10. 1007/s00767-009-0130-0

Zimmermann U, Zötl J (1971) Deuterium- und Sauerstoff-18-Gehalt von Gasteiner Thermal- und Kaltwässern [Deuterium and oxygen 18 content of thermal and cold water of Gastein]. Steir Beitr Hydrogeol 23:127-132 